\title{
INFLUENCE OF EXTRUDED CAMELINA SEED AND NATURAL COLOURANTS ADDITION IN LAYING HENS DIET ON EGGS YOLK COLOUR AND FATTY ACID COMPOSITION
}

\author{
N. Spasevski1 ${ }^{*}$, T. Peulić1 ${ }^{1}$ V. Banjac ${ }^{1}$, R. Čolović ${ }^{1}$, L. Pezo ${ }^{2}$, S. Rakita ${ }^{1}$, N. Puvača ${ }^{3}$, B. Kokić ${ }^{1}$, O. Đuragić1 ${ }^{\text {and }}$ \\ Z. Basić ${ }^{4}$ \\ ${ }^{1}$ Institute of Food Technology, University of Novi Sad, Novi Sad, Serbia \\ ${ }^{2}$ Institute of General and Physical Chemistry, University of Belgrade, Belgrade, Serbia \\ ${ }^{3}$ Department of Engineering Management in Biotechnology, University Business Academy, Serbia \\ ${ }^{4}$ Military Medical Academy, Institute of Hygiene, Belgrade, Serbia \\ "Corresponding author's e-mail: nedeljka.spasevski@fins.uns.ac.rs
}

\begin{abstract}
The aim of this study was to investigate the effects of inclusion of camelina-corn meal co-extrudate (CCM) and natural pigments in hen's diet on colour, fatty acid composition and total tocopherols content of eggs. One hundred and twenty Lohmann Brown laying hens were fed with corn-soybean meal based diet with addition of CCM at different levels: $0 \%$ (control K1 and K2), 16.60\% (C1) and 27.60\% (C2). Control treatments were different in the amount of fat and content of pigments. Control treatment K1 contains 3\% fat with no pigments added, while control treatment $\mathrm{K} 2$ contains $5 \%$ fat with the addition of synthetic pigments. Treatments $\mathrm{C} 1$ and $\mathrm{C} 2$, which contained $1 \%$ carrots and $0.5 \%$ paprika, achieved desirable colour, demanded by consumers, 12.67 and 13.28 RYCF (Roche Yolk Colour Fan), respectively. Eggs from hens fed with CCM had significantly higher level ( $\mathrm{p} \leq 0.001)$ of $\alpha$-linolenic $(3.89 \%$ for $\mathrm{C} 1$ and $4.29 \%$ for $\mathrm{C} 2$ ), docosahexaenoic $(1.38 \%$ for $\mathrm{C} 1$ and $1.34 \%$ for $\mathrm{C} 2)$ and eicosapentaenoic $(0.17 \%$ for $\mathrm{C} 1$ and $0.18 \%$ for $\mathrm{C} 2)$ acids than eggs originated from hens fed with the control diets. The $\omega-6 / \omega-3$ ratios of 1.74 and 1.73 in treatments $\mathrm{C} 1$ and $\mathrm{C} 2$ respectively, were significantly lower $(\mathrm{p} \leq 0.001)$ than $\omega-6 / \omega-3$ ratios in the control treatments $\mathrm{K} 1$ and $\mathrm{K} 2(9.40$ and 8.88 , respectively). Hence, the obtained results showed the possibility of producing functional egg with desirable colour and fatty acid composition by adding CCM and natural pigments in hen's diet.
\end{abstract}

Key words: camelina-corn meal co-extrudate, paprika, carrot, functional egg, tocopherols.

https://doi.org/10.36899/JAPS.2020.6.0154

Published online August 03,2020

\section{INTRODUCTION}

Since olden times, eggs have been regarded as an extremely nutritious and affordable food that is consumed all over the world. By adding nutrients such as omega-3 polyunsaturated fatty acids ( $\omega-3$, PUFA), minerals, vitamins and carotenoids in the laying hen's diets, the nutritive profile of the eggs can be easily enhanced, thus producing the "designed" eggs or functional food (Grčević et al., 2011). Over the past years, many studies have revealed certain compounds that have a positive effect on human health and can be transferred from the laying hens feed into the yolks (Bean and Leeson, 2003; Khan et al., 2012). These eggs with altered nutrition can contribute to human health and nutrition.

The most important $\omega$-3 PUFA in human nutrition is $\alpha$-linolenic acid (ALA, C18:3 $\omega-3$ ) which is a precursor for the synthesis of eicosapentaenoic acid (EPA, C20:5 $\omega-3$ ) and docosahexaenoic acid (DHA, C22:6 (-3). These compounds cannot be synthesized in the human body and the only way is to get them through food (Whelan and Rust, 2006; Colović et al., 2015a).
However, as Simopoulos (2009) state, the critical factor in fatty acid efficacy is not the absolute amounts of $\omega-6$ and $\omega-3$ but their ratio. The $\omega-3 / \omega-6$ ratio should be close to the $1: 1$ since this was the ratio on which humans evolved. A more suitable $\omega-3 / \omega-6$ ratio of fatty acids increases the conversion rate of EPA and DHA from ALA (Simopoulos, 2001).

The most common sources of ALA in human consumption are seeds and vegetable oils, while EPA and DHA are most commonly found in fish and oils of marine organisms (Grčević et al., 2011). One way to increase these $\omega$-fatty acids in eggs is to add seeds of camelina or its products in laying hen's diet. Camelina sativa, also known as "false flax" and "gold of pleasure", despite its high nutritional value and modest agro-ecological requirements for cultivation is still insufficiently exploited in the feed industry. The content of oil in the seed ranges from $30 \%$ to $50 \%$ (Mladenov et al., 2017). Camelina sativa oil contains a high level of $\omega-3$ fatty acids, $30-40 \%$ of ALA, about $15 \%$ of gondoic acid and about 3\% of erucic acid (Mladenov et al., 2017). It also contains $30 \%$ more antioxidants than other dietary oils (Budin et al., 1995). Compared to other edible oils, 
camelina oil is better stabilized and has a longer shelf life (Campbell, 2018).

Anti-nutritional factors present in camelina seed are glucosinolates -13.2 to $36.2 \mu \mathrm{mol} / \mathrm{g}$ dry seed (Schuster and Friedt, 1998). The high level of glucosinolates in feed, which negatively affect digestibility and nutrient utilization in poultry (Pekel et al., 2009; Aziza et al., 2013), can be easily destroyed by heat treatment (Jensen et al., 1995) or hydrolyzed by water soaking (Tyagi, 2002). Among thermal treatments such as micronization, extrusion, or microwave heating, the most effective treatment for reducing glucosinolate content is extrusion, and even more effective is extrusion with moisture (Tripathi and Mishra, 2007). Extrusion of oilseeds is very difficult to perform alone, because of problems with lubrication, limited pellet expansion, and oil spillage. To overcome these problems, another raw material is often added to the oilseeds, mainly a protein component, which shows good oil adsorption capacity. In the present study, corn meal was used because it contains a small amount of oil (about 1\%) due to germ removal, and because corn is used in laying hen's diet in quantities of over $50 \%$, at a low market price and high energy content. The inclusion of such extruded seeds in animal nutrition improves dry matter intake, increases the biological value of proteins and the body weight of individuals (Tripathi and Mishra, 2007).

Although it has not been shown that the colour of the yolks affects the taste of eggs and the content of nutrients, it is one of the main attributes of the sensory quality. The colour of the yolk also depends on the feed quality for the laying hens and thus, can be influenced by the addition of carotenoids (Skřivan et al., 2015). Since the high intake of carotenoid-rich foods has shown a number of positive effects on human health, eggs are considered a food that is extremely suitable for the transfer of carotenoids to the human food chain (Skrrivan and Englmaierová, 2014). In accordance with modern trends in reducing the use of synthetic additives, alternative sources of natural carotenoids are evaluated such as corn, corn gluten, alfalfa (Galobart et al., 2004), tomatoes, certain types of algae, dried foliage, carrot (Hammershøj et al., 2010), paprika, marigold flower (Santos-Bocanegra et al., 2004; Lokaewmanee et al., 2010), as well as the flower of saffron (Rowghani et al., 2006).

The main aim of this study was to produce eggs with functional characteristics by applying natural feed compounds. The investigation aimed at determining how feeding the laying hens with diet containing co-extruded camelina seed and corn meal (CCM) (supplemented with vitamin E) as a source of $\omega-3$ fatty acids, as well as paprika and carrot, as sources of natural pigments, influence basic physical parameters, egg yolk colour, fatty acid content and tocopherols of laying hen eggs.

\section{MATERIALS AND METHODS}

Materials: The experiment with laying hens was conducted in accordance with the principles of the European Union Strategy for the Protection and Welfare of Animals. The experiment was conducted on 120 Lohmann Brown laying hens (in the $44^{\text {th }}$ week of production) for one month. Hens were divided into four treatments ( 2 control and 2 experimental) with a total of thirty hens (six replicates with five birds in cages). All hens were housed in an environmentally controlled experimental facility with the temperature maintained at approximately $22^{\circ} \mathrm{C}$. The house had controlled ventilation and lighting according to hybrid specifications. All hens were supplied with a diet of $110 \mathrm{~g}$ of feed/hen/day while the water was provided ad libitum. The samples were collected on $30^{\text {th }}$ day of the experiment.

In control treatments laying hens were fed with corn-soybean meal basal diet. The first control treatment (K1) contained up to $3 \%$ fat with no pigments added, while second control treatment (K2) contained up to $5 \%$ fat with the addition of synthetic pigments $(0.04 \mathrm{~g} / \mathrm{kg}$ carophyll red and $0.015 \mathrm{~g} / \mathrm{kg}$ carophyll yellow). In the first experimental treatment (C1) $16.60 \%$ of CCM was added $(3 \%$ fat in the complete mixture originated from the $\mathrm{CCM}$ ), while in the second experimental treatment (C2) $27.60 \%$ of CCM was added (5\% fat in the complete mixture originated from the CCM). In both experimental treatments same amounts of natural source of pigments were added ( $1 \%$ carrot and $0.5 \%$ paprika) instead of synthetic pigments. This choice was made based on the preliminary results of the study by Spasevski et al. (2018) which aimed to examine the replacement of synthetic pigments with natural pigments such as marigold, carrots and paprika.

Composition and chemical analysis of complete mixtures with functional additives for feeding laying hens is presented in Table 1. Composition of mixtures was designed using the MX98, Machina Optima (IT Engineering) program.

The extrusion of camelina seed: The process of coextruding corn meal with camelina seed in order to obtain functional feed was conducted at the feed pilot-plant, at the Institute of Food Technology in Novi Sad (Serbia). Camelina seeds were ground using a hammer mill (ABC Inženjering, Pančevo, Serbia) equipped with $2 \mathrm{~mm}$ sieve. Ground camelina seeds were mixed with corn meal (ratio 1:1) in double-shaft pedal mixer (Muyang SLHSJ0.2A, Muyang, Yangzhou, China) for $90 \mathrm{~s}$. Obtained mixture of camelina and corn meal was then extruded using corotating twin-screw extruder (Bühler BTSK 30/28D, 7 sections, extruder barrel length $880 \mathrm{~mm}$, length/diameter ratio $=28: 1$, Bühler, Uzwil, Switzerland). The extruder was equipped with two tempering tools for heating/cooling of sections of jacketed extruder barrel 
using water as a medium. First tempering tool controlled temperature of sections 2-4, while the second controlled temperature of sections 6-7. A die plate that had one 4 $\mathrm{mm}$ diameter opening with cone inlet (total die open area
$12.56 \mathrm{~mm}^{2}$ ) was used. The extrusion parameters used for extrusion of camelina seed-corn meal mixture are presented in Table 2.

Table 1. Experimental diet composition and chemical analysis of the feed.

\begin{tabular}{|c|c|c|c|c|}
\hline \multirow{2}{*}{ Ingredients (\%) } & \multicolumn{4}{|c|}{ Experimental diet } \\
\hline & K1 & $\mathrm{K} 2$ & $\mathrm{C} 1$ & $\mathrm{C} 2$ \\
\hline Corn & 57.60 & 55.40 & & \\
\hline Corn meal & & & 45.80 & 38.80 \\
\hline Co-extruded camelina & & & 16.60 & 27.60 \\
\hline Soybean meal & 20.00 & 20.00 & 15.00 & 11.00 \\
\hline Sunflower meal - $33 \%$ protein & 8.50 & 9.00 & 8.50 & 8.50 \\
\hline Soybean oil & 1.30 & 3.00 & & \\
\hline Yeast & 2.00 & 2.00 & 2.00 & 2.00 \\
\hline Monocalcium phosphate & 1.20 & 1.20 & 1.20 & 1.20 \\
\hline Sodium bicarbonate & 0.10 & 0.10 & 0.10 & 0.10 \\
\hline Premix & 1.00 & 1.00 & 1.00 & 1.00 \\
\hline Limestone & 8.00 & 8.00 & 8.00 & 8.00 \\
\hline Salt & 0.30 & 0.30 & 0.30 & 0.30 \\
\hline Synthetic pigment $(\mathrm{g} / \mathrm{kg})$ & & $0.06^{\mathrm{A}}$ & & \\
\hline Paprika & & & 0.50 & 0.50 \\
\hline Carrot & & & 1.00 & 1.00 \\
\hline \multicolumn{5}{|l|}{ Nutrient composition (\%) } \\
\hline Dry & 89.55 & 89.81 & 91.26 & 91.28 \\
\hline Crude protein & 15.47 & 15.33 & 15.58 & 15.34 \\
\hline Crude fat & 3.86 & 5.51 & 3.83 & 5.66 \\
\hline Crude ash & 11.56 & 11.26 & 11.65 & 11.07 \\
\hline Crude fibre & 5.69 & 6.17 & 5.28 & 5.37 \\
\hline Calcium & 3.73 & 3.94 & 3.90 & 3.83 \\
\hline Total phosphorus & 0.59 & 0.57 & 0.56 & 0.57 \\
\hline Metabolizable energy ${ }^{\mathrm{B}}, \mathrm{MJ} / \mathrm{kg}$ & 11.57 & 11.62 & 11.55 & 11.73 \\
\hline
\end{tabular}

${ }^{\mathrm{A} C}$ Control treatment $\mathrm{K} 2$ contains: $0.04 \mathrm{~g} / \mathrm{kg}$ carophyll red and $0.015 \mathrm{~g} / \mathrm{kg}$ carophyll yellow

${ }^{B}$ Metabolisable energy was calculated mathematically using software package PanonMix (C) 2013

designed for animal feed mixture formulation. $\mathrm{K} 1$ and $\mathrm{K} 2$ - control treatments; $\mathrm{C} 1$ and $\mathrm{C} 2$ - experimental treatments.

Table 2. Extrusion processing parameters.

\begin{tabular}{|c|c|}
\hline \multicolumn{2}{|l|}{ Adjustable extruder parameters } \\
\hline $\begin{array}{l}\text { Set temperature of sections } 2,3 \\
\text { and } 4\left({ }^{\circ} \mathrm{C}\right)\end{array}$ & 125 \\
\hline $\begin{array}{l}\text { Set temperature of sections } 6 \text { and } \\
7\left({ }^{\circ} \mathrm{C}\right)\end{array}$ & 145 \\
\hline Feeding rate $(\mathrm{kg} / \mathrm{h})$ & 45 \\
\hline Screw speed (RPM) & 950 \\
\hline $\begin{array}{l}\text { Dependent extruder parameters } \\
\text { Temperature }{ }^{\mathrm{A}}\left({ }^{\circ} \mathrm{C}\right)\end{array}$ & \\
\hline Section 3 & 119.6 \\
\hline Section 6 & 132.4 \\
\hline Die & 129.0 \\
\hline Die pressure (bar) & 5.0 \\
\hline Torque $^{\mathrm{B}}(\mathrm{Nm})$ & 68.2 \\
\hline $\mathrm{SME}^{\mathrm{C}}(\mathrm{Wh} / \mathrm{kg})$ & 95.1 \\
\hline
\end{tabular}

Output extrusion parameters (section temperatures, die temperature, pressure at the die, motor load and specific mechanical energy) were read directly from the PLC screen of the extruder. For achieving final length of the product, cutter at the outlet of the material from the die of the extruder was fitted with six knives, with a rotational speed set at 250 RPM. After the thermal treatment of camelina seed, the obtained product is highly susceptible to oxidation and polymerization. Therefore, antioxidants, vitamin $\mathrm{E}$ must be added to protect such product. After cooling, vitamin E was added in the coextrudate (CCM) at $1.35 \mathrm{~g} / \mathrm{kg}$ level and mixed in a twinshaft pedal mixer for $90 \mathrm{~s}$. The content of vitamin $\mathrm{E}$ in $\mathrm{C} 1$ and C2 treatment was 224 and $372.4 \mathrm{mg}$ per $\mathrm{g}$ of feed, respectively. It was calculated after the addition of CCM in a final mixture at levels specified in Table 1.

Chemical analysis: Camelina seed and CCM were analysed for moisture, crude ash, crude protein, crude fat 
and crude fibre. All analyses were performed in triplicate. The moisture content was determined according to AOAC (Association of Official Analytical Chemists) Method 934.01. Crude protein content was determined by Kjeldahl method according to the AOAC Method 978.04, crude ash, according to AOAC Method 942.05, crude fat, according to AOAC Method 920.39 and crude fibre according to AOAC Method 978.10 (AOAC, 1998). Content of total glucosinolates was determined according to MSZ-08-1908 (1989), involving absorbency measurement of Pd-complex glucosinolates at $425 \mathrm{~nm}$. A standard curve was constructed with synigrine as a standard.

Determination of the fatty acid composition of oilseeds, co-extrudates and eggs: Lipids from egg yolk were extracted using the Folch method (Folch et al., 1957). Fatty acid methyl esters (FAME) were prepared by transmethylation with a $14 \%$ methanol solution of bortrifluoride (Ivanov et al., 2012). As a solvent, nheptane was used. The obtained samples were analysed by gas chromatography on an Agilent 7890A system (Agilent Technologies, Santa Clara, CA, USA) as described by Spasevski et al. (2016). The GC regime was previously described by Čolović et al. (2015b).

Determination of the content and composition of tocopherol in egg yolks: The tocopherols were extracted from egg yolk after saponification (with aqueous solution of $\mathrm{KOH}$ and $95 \%$ ethanol) and extraction using cold deionised water and hexane. Preparation of samples was described by Rabrenović et al. (2016). The samples were analysed by high pressure liquid chromatography (Waters M600E, USA) on a Nucleosil 50-5 C18 reversed phase column with a fluorescence detector (Shimadzu RF-535, Japan). Mobile phase was $95 \%$ ethanol with a flow rate of $1.0 \mathrm{~mL} / \mathrm{min}$.

Instrumental methods for determination of colour: A Chromameter colour analyzer (Model CR-400, Minolta Co., Osaka, Japan) with attachment CR-A33f was used to measure the colour of egg yolk in terms of CIELab colour system where the colour values were expressed as $\mathrm{L}^{*}$ (lightness), $\mathrm{a}^{*}$ (redness/greenness) and $\mathrm{b}^{*}$ (yellowness/blueness).

Coloration of the egg yolk was measured visually according to RYCF (Hoffmann-La Roche Ltd, Basel, Switzerland), which is a scale of colours ranging from 1 (light pale) to 15 (dark orange).

$\beta$-carotene was determined according to Spasevski et al. (2016). The spectrophotometric method is based on measuring the presence of pigments in yolk like total of $\beta$-carotene. Acetone was used for extraction and the results were expressed as $\mu \mathrm{g}$ of $\beta$-carotene per $g$ of the sample.

Statistical analysis: Descriptive statistical data were expressed by means \pm standard error (SE), $n=10$ repetitions for each treatment. Statistica software, version 10 (StatSoft Inc. 2010, USA) ${ }^{\circledR}$ was utilized to perform the analysis of variance (ANOVA) of the obtained results. Significant differences among treatment means were analysed by Tukey's HSD test.

\section{RESULTS AND DISCUSSION}

The aim of this study was to examine the possibility of replacing synthetic pigments, which are nowadays used in conventional egg production, with natural sources of pigments and their influence on yolk colour, as well as the possibility of changing the egg nutritive profile by adding co-extruded camelina seed rich in omega-3 fatty acids in laying hens nutrition with the aim of functional eggs production. Based on the literature, it is known that the addition of fat feeds rich in polyunsaturated fatty acids, especially omega-3, into the diet of laying hens leads to an increase in the content of these fatty acids in eggs (Corino et al., 2002). In this study camelina seed as a very rich source of omega 3 fatty acids was chosen. The camelina seed contained high amount of protein $(30.61 \%)$ and fat $(32.14 \%)$, but also high level of glucosinolates $(28.09 \mu \mathrm{mol} / \mathrm{g})$, which are harmful to farm animals (European Food Safety, 2008) wherefore it was necessary to apply some thermal treatment. The extrusion process is most effective for reducing the glucosinolate content of oilseeds (Tripathi and Mishra, 2007). However, when extruding oilseeds containing large amounts of fat, problems such as lubrication and limited product expansion, as well as oil leakage, change the quality of the final product. Therefore, it is necessary to extrude oilseeds with another raw material that shows good oil adsorption capacity. In our studies, corn meal was used for two reasons. The first reason is that corn is otherwise added to the feed of the laying hens in an amount of over $50 \%$, and the second reason is that the germ has been removed so that this corn meal contains less than $1 \%$ oil. Extrusion of a 50:50 mixture of corn meal with oilseeds resulted in functional co-extrudates (CCM) in which almost the entire amount of oil came from oilseeds, which can be seen by comparing the fatty acid composition of camelina seeds with the fatty acid composition of the CCM shown in Table 3 .

The complete chemical and fatty acid compositions of camelina seed and co-extrudate CCM are shown in Table 3. High level of protein and fat, especially high level of PUFAs and MUFAs which constituted $54.33 \%$ and $36.91 \%$ of total fat, respectively, makes it a suitable source of plant protein and essential $\omega-3$ and $\omega-6$ fatty acids in laying hen's diet (Table 3 ). High level of $\alpha$-linolenic acid (34.62\%), eicosenoic acid (17.05\%), linoleic acid (16.56\%) and oleic acid (16.47\%) obtained in this study (Table 3) were in the accordance 
with other reported results (Budin et al., 1995; Aziza et al., 2013; Cherian and Quezada, 2016).

CCM represented a new functional product with added values, because of high level of PUFAs (56.51\%) and MUFAs (34.45\%) that constituted from $\alpha$-linolenic acid (34.85\%), linoleic acid (18.79\%), oleic acid $(17.06 \%)$ and eicosenoic acid (14.43\%). The extrusion process significantly lowered the content of glucosinolates (from $28.09 \mu \mathrm{mol} / \mathrm{g}$ to $4.19 \mu \mathrm{mol} / \mathrm{g}$ ) in CCM while the other fatty acids were depicted in high levels, almost the same as they were in camelina seed (Table 3).

The influence of addition of CCM on the internal egg quality characteristics during one month feeding of laying hens is presented in Table 4.

Table 3. Chemical and fatty acid composition of camelina seed and co-extrudate.

\begin{tabular}{|c|c|c|}
\hline Chemical composition $(\%)$ & $\mathrm{CS}^{\mathrm{A}}$ & $\mathrm{CCM}^{\mathrm{B}}$ \\
\hline Moisture & $6.49 \pm 0.06^{\mathrm{a}}$ & $5.93 \pm 0.08^{b}$ \\
\hline Crude protein & $30.61 \pm 0.15^{\mathrm{a}}$ & $19.94 \pm 0.21^{b}$ \\
\hline Crude fat & $32.14 \pm 0.11^{\mathrm{a}}$ & $18.13 \pm 0.16^{\mathrm{b}}$ \\
\hline Crude ash & $3.45 \pm 0.04^{\mathrm{a}}$ & $2.01 \pm 0.06^{\mathrm{b}}$ \\
\hline Crude fibre & $17.85 \pm 0.13^{\mathrm{a}}$ & $3.49 \pm 0.08^{\mathrm{b}}$ \\
\hline Glucosinolates $(\mu \mathrm{mol} / \mathrm{g})$ & $28.09 \pm 0.36^{\mathrm{a}}$ & $4.19 \pm 0.14^{\mathrm{b}}$ \\
\hline \multicolumn{3}{|c|}{ Fatty acid composition (as \% of total fatty acid methyl esters) } \\
\hline C16:0 (palmitic acid) & $4.67 \pm 0.01^{\mathrm{b}}$ & $5.24 \pm 0.10^{\mathrm{a}}$ \\
\hline C18:0 (stearic acid) & $2.50 \pm 0.06$ & $2.45 \pm 0.04$ \\
\hline 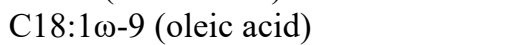 & $16.47 \pm 0.18^{b}$ & $17.06 \pm 0.22^{\mathrm{a}}$ \\
\hline 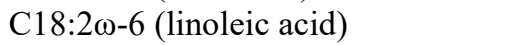 & $16.56 \pm 0.31^{\mathrm{b}}$ & $18.79 \pm 0.06^{\mathrm{a}}$ \\
\hline 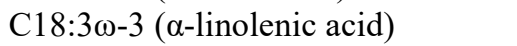 & $34.62 \pm 0.12$ & $34.85 \pm 0.43$ \\
\hline C20:1 $\omega-9$ (eicosenoic acid) & $17.05 \pm 0.06^{\mathrm{a}}$ & $14.43 \pm 0.05^{b}$ \\
\hline C20:2 $\omega-6$ (eicosadienoic acid) & $1.76 \pm 0.03^{\mathrm{a}}$ & $1.61 \pm 0.01^{\mathrm{b}}$ \\
\hline C20:3 $\omega-6$ (dihomo- $\gamma$-linolenic acid) & $1.39 \pm 0.01^{\mathrm{a}}$ & $1.26 \pm 0.01^{\mathrm{b}}$ \\
\hline $\mathrm{C} 22: 1 \omega-9$ (erucic acid) & $3.38 \pm 0.15^{\mathrm{a}}$ & $2.96 \pm 0.04^{b}$ \\
\hline SFA $^{\mathrm{C}}$ & $8.67 \pm 0.13^{b}$ & $9.03 \pm 0.16^{\mathrm{a}}$ \\
\hline MUFA $^{\mathrm{D}}$ & $36.91 \pm 0.27^{\mathrm{a}}$ & $34.45 \pm 0.20^{\mathrm{b}}$ \\
\hline PUFA $^{\mathrm{E}}$ & $54.33 \pm 0.39^{b}$ & $56.51 \pm 0.37^{\mathrm{a}}$ \\
\hline$\omega-6$ & $19.71 \pm 0.27^{\mathrm{b}}$ & $21.66 \pm 0.07^{\mathrm{a}}$ \\
\hline$\omega-3$ & $34.62 \pm 0.12$ & $34.85 \pm 0.43$ \\
\hline$\omega-6 / \omega-3$ & $0.57 \pm 0.00^{\mathrm{b}}$ & $0.62 \pm 0.01^{\mathrm{a}}$ \\
\hline
\end{tabular}

Table 4. Effect of dietary inclusion of CCM on egg quality after 30 days of the feeding period.

\begin{tabular}{lcccc}
\hline Physical properties & K1 & K2 & C1 & C2 \\
Egg weight, (g) & $66.50 \pm 1.42$ & $67.55 \pm 1.45$ & $66.71 \pm 1.77$ & $66.57 \pm 2.21$ \\
Yolk weight, (\%) & $25.67 \pm 0.60$ & $24.58 \pm 0.60$ & $25.78 \pm 0.79$ & $25.73 \pm 0.63$ \\
Albumen weight,(\%) & $63.39 \pm 0.63$ & $64.03 \pm 0.66$ & $63.91 \pm 0.85$ & $63.84 \pm 0.60$ \\
Shell weight, (\%) & $10.94 \pm 0.44$ & $11.39 \pm 0.32$ & $10.31 \pm 0.19$ & $10.42 \pm 0.25$ \\
Shell thickness, (mm) & $0.34 \pm 0.03$ & $0.35 \pm 0.03$ & $0.35 \pm 0.00$ & $0.34 \pm 0.00$ \\
Yolk index & $40.92 \pm 0.73$ & $44.76 \pm 0.95$ & $44.14 \pm 1.20$ & $42.27 \pm 1.33$ \\
Yolk pH & $6.04 \pm 0.00$ & $6.02 \pm 0.00$ & $6.02 \pm 0.01$ & $6.06 \pm 0.01$ \\
Albumen pH & $8.86 \pm 0.02$ & $8.82 \pm 0.01$ & $8.80 \pm 0.01$ & $8.72 \pm 0.02$ \\
\hline
\end{tabular}

Between results within the same row in the table no significant differences (at p>0.05 level). K1 and K2 - control treatments; C1 and $\mathrm{C} 2$ - experimental treatments.

According to the obtained results, it can be observed that the differences in the nutrition of laying hens did not significantly $(\mathrm{p}>0.05)$ influence the egg weight, yolk weight, albumen weight, shell weight, shell thickness, yolk index, yolk $\mathrm{pH}$ or albumen $\mathrm{pH}$ during the whole period of trial (Table 4). The obtained results were in the agreement with Cherian et al. (2009), Kakani et al. (2012) and Vasilachi et al. (2012) who reported that the 
addition of camelina meal to laying hens diet did not deteriorate egg quality parameters. Conversely, Cherian and Quezada (2016) reported a decrease in egg and albumen weight in hens fed with $10 \%$ camelina seed, while Aziza et al. (2013) observed decreased yolk weight when laying hens were fed with $10 \%$ camelina meal.

The influence of inclusion of CCM and natural pigments in the hens diet on the parameters of egg yolk colour was demonstrated in Table 5. By adding natural pigments in $\mathrm{C} 1$ and $\mathrm{C} 2$ treatments the content of redness $\left(a^{*}\right), \quad \beta$-carotene, and RYCF significantly increased $(\mathrm{p} \leq 0.05)$ while the content of lightness $\left(L^{*}\right)$ significantly decreased $(\mathrm{p} \leq 0.05)$ in comparison with control treatment $\mathrm{K} 1$ where pigments were not added. The changes in the yellowness $\left(b^{*}\right)$ were not observed between this treatments. Also, the content of redness $\left(a^{*}\right)$ and RYCF in experimental treatment $\mathrm{C} 1$ was significantly lower $(\mathrm{p} \leq 0.05)$ than in control treatment $\mathrm{K} 2$ while significant changes were not observed $(p>0.05)$ between experimental treatment $\mathrm{C} 2$ and control treatment $\mathrm{K} 2$, although the same amount of pigments $(1 \%$ carrot and $0.5 \%$ paprika) were added in both experimental treatments. This occurrence was perhaps due to the higher fat level that treatment $\mathrm{C} 2$ had (5\%) in comparison with treatment $\mathrm{C} 1(3 \%)$, which contributed to the better solubility of the pigments in treatment $\mathrm{C} 2$ and thus to the colour which is closer to parameters of the colour of egg yolk in treatment $\mathrm{K} 2$. On the other hand, parameters of colour between $\mathrm{C} 1$ and $\mathrm{C} 2$ were not significantly different $(p>0.05)$, which indicates that the increased content of CCM did not affect the colour of egg yolk and that only the addition of natural pigments in laying hen's diet influenced the parameters of egg yolk colour. Vasilachi et al. (2012) and Cherian and Quezada (2016) reported that the addition of $10 \%$ camelina seed or $3 \%$ and $6 \%$ of camelina meal in hens diet didn't significantly effect egg yolk colour.

Yolk colour is highly subjective and varies considerably from one region to another, but in most of the countries of Europe and Asia, consumers prefer yellow-orange yolks, which are about 10 to $14 \mathrm{RYCF}$ (Galobart et al., 2004; Chowdhury et al., 2008). In that respect, acceptable egg yolk colour values (12.67-13.28 per RYCF) were achieved in both experimental treatments (with $1 \%$ of carrots and $0.5 \%$ of paprika and $\mathrm{CCM}$ ), and thus these eggs are preferable for consumers. The RYCF values of egg yolk colour are in accordance with literature data (Galobart et al., 2004; Hernandez, 2005; Kralik et al., 2006; Bovškova et al., 2014).

Table 5. Effect of dietary inclusion of CCM, carrot and paprika on yolk colour during 30 days of the feeding period.

\begin{tabular}{lcccc}
\hline Variable & K1 & K2 & C1 & C2 \\
$L^{*}$ & $51.47 \pm 0.54^{\mathrm{a}}$ & $48.81 \pm 0.54^{\mathrm{b}}$ & $48.79 \pm 0.76^{\mathrm{b}}$ & $47.93 \pm 0.63^{\mathrm{b}}$ \\
$a^{*}$ & $0.56 \pm 0.25^{\mathrm{c}}$ & $13.32 \pm 0.22^{\mathrm{a}}$ & $9.61 \pm 0.32^{\mathrm{b}}$ & $10.90 \pm 1.01^{\mathrm{ab}}$ \\
$b^{*}$ & $38.08 \pm 1.01^{\mathrm{a}}$ & $36.20 \pm 1.20^{\mathrm{a}}$ & $36.17 \pm 1.30^{\mathrm{a}}$ & $34.88 \pm 1.11^{\mathrm{a}}$ \\
$\beta$-carotene $(\mu \mathrm{g} / \mathrm{g})$ & $29.97 \pm 0.13^{\mathrm{b}}$ & $55.15 \pm 1.04^{\mathrm{a}}$ & $49.36 \pm 0.51^{\mathrm{a}}$ & $48.80 \pm 0.79^{\mathrm{a}}$ \\
RYCF & $8.28 \pm 0.28^{\mathrm{c}}$ & $14.17 \pm 0.22^{\mathrm{a}}$ & $12.67 \pm 0.22^{\mathrm{b}}$ & $13.28 \pm 0.35^{\mathrm{ab}}$ \\
\hline
\end{tabular}

${ }^{\mathrm{a}-\mathrm{c}}$ Different letters printed in superscript within the same row in the table show significantly different means of observed data (at $\mathrm{p} \leq 0.05$ level). $\mathrm{K} 1$ and $\mathrm{K} 2$ - control treatments; $\mathrm{C} 1$ and $\mathrm{C} 2$ - experimental treatments.

Total fatty acids (FA) profile of egg yolk is presented in Table 6. With the addition of CCM in hen's diet, the content of total SFA (C14:0, C16:0, C18:0, C22:0) was significantly lower $(\mathrm{p} \leq 0.01)$ in experimental treatments $\mathrm{C} 1(35.76 \%)$ and $\mathrm{C} 2(36.57 \%)$ in comparison with the control treatments K1 $(40.21 \%)$ and $\mathrm{K} 2$ (38.97\%). This reduction can be explained by the significant $(\mathrm{p} \leq 0.05)$ reduction of the content of the palmitic acid, major saturated fatty acid in feed mixtures. There were no significant differences $(p>0.05)$ in the content of other saturated fatty acids in experimental treatments compared to the control ones, except in the content of behenic acid in the experimental treatment $\mathrm{C} 1$. These results were in the accordance with the previous researches of Cherian et al. (2009) and Aziza et al. (2013) who reported that the addition of camelina meal decrease the content of palmitic acids in egg yolk.

The content of total MUFAs significantly increased $(p \leq 0.01)$ in egg yolk from laying hens fed
CCM due to significantly higher $(\mathrm{p} \leq 0.01)$ content of oleic acid (major MUFA) and eicosenoic acid in experimental treatments $\mathrm{C} 1$ and $\mathrm{C} 2$ in comparison with control treatments $\mathrm{K} 1$ and $\mathrm{K} 2$. The content of palmitoleic acid was higher in treatments where hens were fed $3 \%$ fat $(\mathrm{K} 1$ and $\mathrm{C} 1$ ) than in treatments where hens were fed $5 \%$ fat (K2 and $\mathrm{C} 2$ ).

PUFAs content had higher values in eggs from laying hens fed with higher fat content $(5 \%$ in $\mathrm{K} 2$ and $\mathrm{C} 2$ ) in comparison with eggs from laying hens fed with lower fat content ( $3 \%$ in $\mathrm{K} 1$ and $\mathrm{C} 1$ ). Feeding laying hens with different sources of fat, in control treatments with corn and soybean oil, and in experimental treatments with co-extrudates of camelina, led to the increase in $\omega-6$ fatty acids in the control treatments in contrary to the increase of $\omega-3$ fatty acids in the experimental treatments. For this reason, the content of PUFAs between control and experimental treatments were no significant $(p>0.05)$ after 30 days of the feeding period. 
Table 6. Content of fatty acid composition in egg yolk during 30 days of the feeding period.

\begin{tabular}{|c|c|c|c|c|}
\hline Fatty acid & K1 & K2 & C1 & $\mathbf{C 2}$ \\
\hline Myristic acid (C14:0) & $0.31 \pm 0.01^{\mathrm{a}}$ & $0.27 \pm 0.01^{\mathrm{a}}$ & $0.29 \pm 0.00^{\mathrm{a}}$ & $0.25 \pm 0.00^{\mathrm{a}}$ \\
\hline Palmitic acid (C16:0) & $28.26 \pm 0.06^{\mathrm{a}}$ & $26.79 \pm 0.09^{b}$ & $24.43 \pm 0.03^{\mathrm{c}}$ & $24.52 \pm 0.13^{\mathrm{c}}$ \\
\hline Stearic acid (C18:0) & $11.07 \pm 0.03^{\mathrm{a}}$ & $11.46 \pm 0.07^{\mathrm{a}}$ & $10.53 \pm 0.01^{\mathrm{a}}$ & $11.26 \pm 0.22^{\mathrm{a}}$ \\
\hline Behenic acid (C22:0) & $0.26 \pm 0.01^{\mathrm{a}}$ & $0.26 \pm 0.01^{\mathrm{a}}$ & $0.18 \pm 0.00^{\mathrm{b}}$ & $0.20 \pm 0.00^{\mathrm{ab}}$ \\
\hline $\mathbf{S F A}^{\mathrm{A}}$ & $40.21 \pm 0.06^{\mathrm{a}}$ & $38.97 \pm 0.09^{a}$ & $35.76 \pm 0.06^{b}$ & $36.57 \pm 0.35^{b}$ \\
\hline Palmitoleic acid (C16:1) & $2.44 \pm 0.04^{\mathrm{a}}$ & $1.72 \pm 0.03^{b}$ & $2.41 \pm 0.04^{\mathrm{a}}$ & $1.93 \pm 0.03^{b}$ \\
\hline 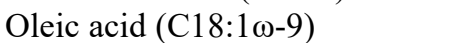 & $42.12 \pm 0.41^{\mathrm{ab}}$ & $41.85 \pm 0.38^{\mathrm{b}}$ & $45.93 \pm 0.09^{\mathrm{a}}$ & $44.44 \pm 0.22^{\mathrm{ab}}$ \\
\hline 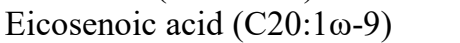 & $0.00 \pm 0.00^{\mathrm{b}}$ & $0.00 \pm 0.00^{\mathrm{b}}$ & $0.52 \pm 0.05^{\mathrm{a}}$ & $0.53 \pm 0.02^{\mathrm{a}}$ \\
\hline MUFA $^{\mathbf{B}}$ & $44.91 \pm 0.35^{b c}$ & $43.97 \pm 0.32^{c}$ & $49.25 \pm 0.00^{\mathrm{a}}$ & $47.35 \pm 0.19^{a b}$ \\
\hline 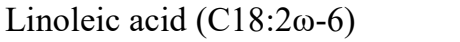 & $13.19 \pm 0.23^{\mathrm{a}}$ & $14.90 \pm 0.36^{\mathrm{a}}$ & $9.43 \pm 0.02^{b}$ & $9.89 \pm 0.13^{b}$ \\
\hline $\operatorname{ALA}^{\mathrm{C}}(\mathrm{C} 18: 3 \omega-3)$ & $0.77 \pm 0.03^{b}$ & $0.98 \pm 0.03^{\mathrm{b}}$ & $3.89 \pm 0.07^{\mathrm{a}}$ & $4.29 \pm 0.09^{\mathrm{a}}$ \\
\hline 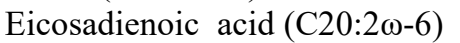 & $0.14 \pm 0.00^{\mathrm{a}}$ & $0.14 \pm 0.00^{\mathrm{a}}$ & $0.05 \pm 0.02^{\mathrm{a}}$ & $0.13 \pm 0.00^{\mathrm{a}}$ \\
\hline $\mathrm{EPA}^{\mathrm{D}}(\mathrm{C} 20: 5 \omega-3)$ & $0.03 \pm 0.00^{\mathrm{b}}$ & $0.04 \pm 0.00^{\mathrm{b}}$ & $0.17 \pm 0.00^{\mathrm{a}}$ & $0.18 \pm 0.00^{\mathrm{a}}$ \\
\hline $\mathrm{DHA}^{\mathrm{E}}(\mathrm{C} 22: 6 \omega-3)$ & $0.62 \pm 0.03^{b}$ & $0.69 \pm 0.03^{b}$ & $1.38 \pm 0.07^{\mathrm{a}}$ & $1.34 \pm 0.05^{\mathrm{a}}$ \\
\hline PUFA $^{\mathrm{F}}$ & $14.87 \pm 0.30^{\mathrm{a}}$ & $17.00 \pm 0.26^{a}$ & $14.99 \pm 0.06^{\mathrm{a}}$ & $16.08 \pm 0.17^{a}$ \\
\hline
\end{tabular}

${ }^{a b c}$ Different letters printed in superscript within the same row in the table show significantly different means of observed data. ${ }^{\text {ASFA - }}$ saturated fatty acids; ${ }^{\mathrm{B}}$ MUFA - monounsaturated fatty acids; ${ }^{\mathrm{C}} \mathrm{ALA}-\alpha$-linolenic acid, ${ }^{\mathrm{D}}$ EPA-eicosapentaenoic acid; ${ }^{\mathrm{E}} \mathrm{DHA}-$

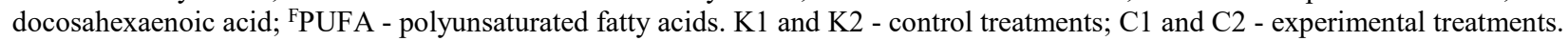

ALA, EPA and DHA were significantly higher $(\mathrm{p} \leq 0.001)$ in both experimental treatments than in control treatments, which can be explained by the addition of CCM in laying hens diet. Thus, the content of ALA was 5 times higher in the experimental treatment $\mathrm{C} 1(3.89 \%)$ than in control treatment $\mathrm{K} 1(0.77 \%)$ and 4 times higher than in control treatment K2 $(0.98 \%)$. ALA level was 5.6 and 4.4 times higher in the experimental treatment $\mathrm{C} 2$ $(4.29 \%)$ than it was in the control treatments K1 and K2, respectively. EPA content was from 4.3 to 6 times higher in experimental treatments $\mathrm{C} 1$ and $\mathrm{C} 2$ than in control treatments $\mathrm{K} 1$ and $\mathrm{K} 2$, while DHA content was 2 times higher in experimental treatments. Obtained results were very desirable from the point of human health and justifies the use of CCM. The results in this study were in accordance with other research (Rokka et al., 2002; Valkonen et al., 2007; Aronen et al., 2009; Cherian et al., 2009; Kakani et al., 2012; Aziza et al., 2013; Cherian and Quezada, 2016).

Content of linoleic acid was significantly lower $(\mathrm{p} \leq 0.05)$ in eggs from experimental treatments $\mathrm{C} 1$ $(9.43 \%)$ and $\mathrm{C} 2(9.89 \%)$ in comparison with the control treatments K1 $(13.19 \%)$ and K2 $(14.90 \%)$. These results can be explain by replacement of corn rich in linoleic acid in control treatments with CCM and corn meal in experimental treatments. Likewise, substitution of corn with corn meal and CCM led to a significantly lower $(p \leq 0.001) \omega-6 / \omega-3$ ratio in experimental treatments $\mathrm{C} 1$ and $\mathrm{C} 2$ compared to the control treatments $\mathrm{K} 1$ and $\mathrm{K} 2$ (Fig. 1).

Total content of $\omega-6$ fatty acids was significantly higher $(p \leq 0.001)$ in the control treatments K1 $(13.33 \%)$ and $\mathrm{K} 2(15.04 \%)$ than in experimental treatments $\mathrm{C} 1$ (9.48\%) and $\mathrm{C} 2(10.03 \%)$, while the total content of $\omega-3$ fatty acids was significantly higher $(p \leq 0.001)$ in experimental treatments $\mathrm{C} 1(5.44 \%)$ and $\mathrm{C} 2(5.80 \%)$ than in control treatments K1 (1.42\%) and K2 (1.71\%).

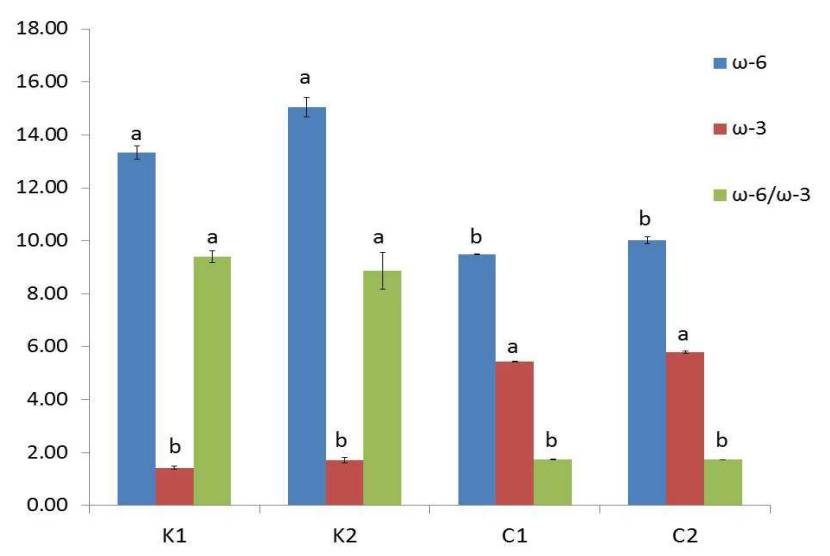

Fig. 1. Changes in total content of $\omega-3$ and $\omega-6$ fatty acids

${ }^{a b}$ Means between treatments and within a fatty acid type without a common letter differ significantly $(\mathrm{p} \leq 0.001)(\mathrm{K} 1$ and $\mathrm{K} 2$ - control treatments, $\mathrm{C} 1$ and $\mathrm{C} 2$ - experimental treatments).

The $\omega-6 / \omega-3$ ratio was significantly lower $(p \leq 0.001)$ in experimental treatments $\mathrm{C} 1(1.74)$ and $\mathrm{C} 2$ (1.73) than in control treatments K1 (9.40) and K2 (8.88).

This ratio was below 2 in both experimental treatments $\mathrm{C} 1$ and $\mathrm{C} 2$, which was lower compared to the $\omega-6 / \omega-3$ ratio from the previously published studies in which the additions of camelina meal or seed in laying hens diet were investigated (Rokka et al., 2002; Cherian et al., 2009; Kakani et al., 2012; Aziza et al., 2013; Cherian and Quezada, 2016). 
Total tocopherols profile in egg yolk is presented in Fig. 2. The content of total tocopherols was significantly higher $(p \leq 0.05)$ in eggs from hens fed control diet with 5\% fat (K2) in comparison with control diets where the hen fed with $3 \%$ fat (K1). The tocopherol content of egg yolk from hens fed diets enriched with vitamin $\mathrm{E}$ was significantly higher $(p \leq 0.05)$ than those from the hens fed with the control diets. An increased supply of CCM in the diet linearly increased the amount of tocopherol in the egg yolk. Thus, tocopherol content in the experimental treatment of $\mathrm{C} 1$ was 9 and 2.5 times higher compared to the control treatment $\mathrm{K} 1$ and $\mathrm{K} 2$, respectively. In the experimental treatment $\mathrm{C} 2$ tocopherol content was 14 and 4 times higher compared to the control treatments K1 and K2, respectively. The obtained results were in the agreement with Hayat et al. (2010).

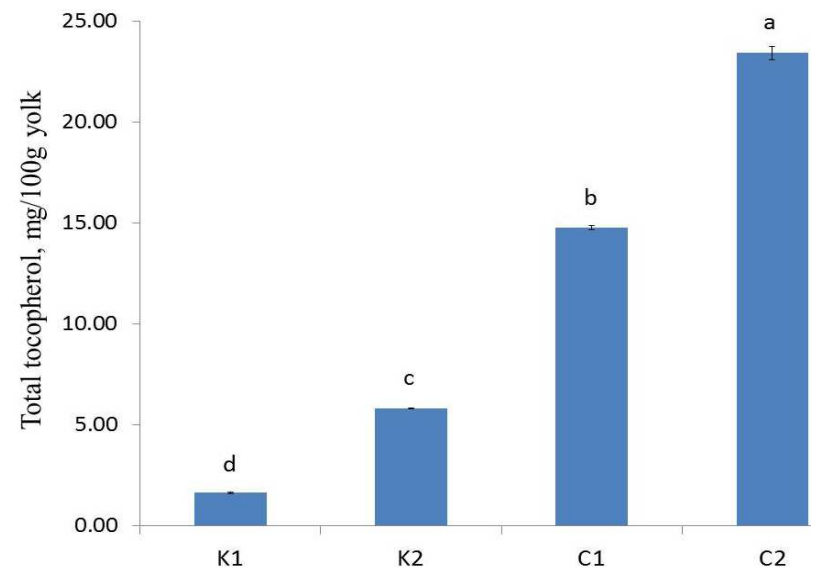

Fig. 2. Content of total tocopherols in the egg yolk of laying hens

${ }^{\mathrm{a}-\mathrm{d}}$ Means between treatments without a common letter differ significantly $(\mathrm{p} \leq 0.05)(\mathrm{K} 1$ and $\mathrm{K} 2-$ control treatments, $\mathrm{C} 1$ and $\mathrm{C} 2$ - experimental treatments)

Conclusion: Extrusion of camelina seed and corn meal mixture successfully provided a new functional product with added value (CCM) due to its high PUFAs (56.51\%) and MUFAs (34.45\%) level, as well as low glucosinolates content $(4.19 \mu \mathrm{mol} / \mathrm{g})$.

Inclusion of CCM in hen's diet did not negatively affect any of egg quality parameters. Also, the addition of CCM in combination with natural pigments ( $1 \%$ carrot and $0.5 \%$ paprika) gained desired values of colour 12.67-13.28 RYCF.

The addition of functional product $\mathrm{CCM}$ in hen's diet significantly lowered the content of SFA and increased the content of MUFA and PUFA, with a special focus on higher values of ALA, EPA and DHA in the experimental treatments in comparison with the control ones. Also, egg yolk from hens fed camelina-corn meal co-extrudate had a lower level of $\omega-6$ and a higher level of $\omega-3$ fatty acids in comparison to yolk from hens fed the control diet. This lead to the low $\omega-6 / \omega-3$ ratio (bellow 2) in the experimental treatments.
The obtained results from this study indicated that the addition of CCM and natural pigments in hen's diet gives the possibility to produce functional egg with attractive colour for customers and desirable fatty acid composition.

Acknowledgements: This work was supported by Ministry of Education, Science and Technological Development of the Republic of Serbia, contract number 451-03-68/2020-14/200222.

\section{REFERENCES}

Aronen, I., E. Valkonen, T. Tupasela, J. Hiidenhovi, and J. Valaja (2009). The effect of Camelina sativa cake on fatty acid composition and sensory quality of eggs and broiler meat, In Proceedings of the 19th European symposium on the quality of poultry meat and XIII European symposium on the quality of eggs and egg products. pp. 111. Turku, Finland.

Association of Analytical Communities (AOAC) (1998). Official Methods of Analysis (16 ${ }^{\text {th }}$ ed.). Gaithersburg, MD, USA.

Aziza, A.E., A.K. Panda, N. Quezada, and G. Cherian (2013). Nutrient digestibility, egg quality, and fatty acid composition of brown laying hens fed camelina or flaxseed meal. J Appl Poultry Res. 22(4): 832-841.

Bean, L.D., and S. Leeson (2003). Long-term effects of feeding flaxseed on performance and egg fatty acid composition of brown and white hens. Poult Sci. 82(3): 388-394.

Bovšková, H., K. Miková, and Z. Panovská (2014). Evaluation of egg yolk colour. Czech J. Food Sci. 32(3): 213-217.

Budin, J.T., W.M. Breene, and D.H. Putnam (1995). Some compositional properties of camelina (Camelina sativa L. Crantz) seeds and oils. J Am Oil Chem Soc. 72(3): 309-315.

Campbell, M. (2018). Camelina- An alternative oil crop. In Biokerosene, Springer, Berlin, pp. 259-275.

Cherian, G., A. Campbell, and T. Parker (2009). Egg quality and lipid composition of eggs from hens fed Camelina sativa. J. Appl. Poult. Res. 18(2): 143-150.

Cherian, G., and N. Quezada (2016). Egg quality, fatty acid composition and immunoglobulin $\mathrm{Y}$ content in eggs from laying hens fed full fat camelina or flax seed. J Anim Sci Biotechno. 7: 15.

Chowdhury, S.D., B.M. Hassin, S.C. Das, M.H. Rashid, and A.J.M. Ferdaus (2008). Evaluation of marigold flower and orange skin as sources of xanthophyll pigment for the improvement of egg yolk color. J. Poult. Sci. 45: 265-272. 
Corino, C., S. Magni, E. Pagliarini, R. Rossi, G. Pastorelli, and L.M. Chiesa (2002). Effects of dietary fats on meat quality and sensory characteristics of heavy pig loins. Meat Science 60: $1-8$.

Čolović, D.S., J.J. Berenji, A.R. Levart, J.K. Salobir, J.D. Lević, R.R. Čolović, and S.J. Popović (2015a). Fatty acid composition and natural antioxidant capacity of ten Serbian linseed cultivars. Food and Feed Research 42(2): 139-145.

Čolović, D., J. Lević, I. Čabarkapa, R. Čolović, Lj. Lević, and I. Sedej (2015b). Stability of an extruded, linseed-based functional feed additive with the supplementation of vitamin E and carvacrol. J. Anim. Feed Sci. 24(4): 348-357.

European Food Safety Authority (2008). Glucosinolates as undesirable substances in animal feed Scientific Opinion of the Panel on Contaminants in the Food Chain. The EFSA J. 590: 1-76.

Folch, J., M. Lees, and S.G. Sloane (1957). A simple method for the isolation and purification of total lipids from animal tissues. J. Biol. Chem. 226: 497-509.

Galobart, J., R. Sala, X. Rincón-Carruyo, E. Manzanilla, B. Vila, and J. Gasa (2004). Egg yolk color as affected by saponification of different natural pigmenting sources. J. Appl. Poult. Res. 13: 328-334.

Grčević, M., Z. Gajčević-Kralik, G. Kralik, and S. Ivanković (2011). Kokošje jaje kao funkcionalna namirnica. Krmiva: Časopis o hranidbi životinja, proizvodnji i tehnologiji krme 53: 93-100.

Hammershøj, M., U. Kidmose, and S. Steenfeldt (2010). Deposition of carotenoids in egg yolk by shortterm supplement of coloured carrot (Daucus carota) varieties as forage material for egglaying hens. J Sci Food Agric. 90(7): 1163-1171.

Hayat, Z., G. Cherian, T.N. Pasha, F.M. Khattak, and M.A. Jabbar (2010). Oxidative stability and lipid components of eggs from flax-fed hens: Effect of dietary antioxidants and storage. Poult Sci. 89(6): 1285-1292.

Hernandez, J. (2005). European consumer surveys about egg quality: How to improve the nutritional value. XI ${ }^{\text {th }}$ European Symposium on the Quality of Eggs and Egg Products, Doorwerth, Netherlands. pp 23-26.

Ivanov, D.S., R.R. Čolović, J.D. Lević, and S.A. Sredanović (2012). Optimization of supercritical fluid extraction of linseed oil using RSM. Eur. J. Lipid Sci. Tech. 114(7): 807-815.

Jensen, S.K., Y.G. Liu, and B.O. Eggum (1995). The effect of heat treatment on glucosinolates and nutritional value of rapeseed meal in rats. Anim. Feed Sci. Tech. 53(1): 17-28.
Kakani, R., J. Fowler, A.U. Haq, E.J. Murphy, T.A. Rosenberger, M. Berhow, and C.A. Bailey (2012). Camelina meal increases egg n-3 fatty acid content without altering quality or production in laying hens. Lipids 47(5): 519 526.

Khan, R.U., S. Naz, Z. Nikousefat, V. Tufarelli, M. Javdani, M.S. Qureshi, and V. Laudadio (2012). Potential applications of ginger (Zingiber officinale) in poultry diets. World Poultry Sci. J. 68(2): 245-252.

Kralik, G., Z. Tolušić, Z. Gajčević, I. Kralik, and D. Hanžek (2006). Commercial quality evaluation of different weight grade eggs. Acta Agraria Kaposváriensis 10(2): 199-205.

Lokaewmanee, K., K. Yamauchi, T. Komori and K. Saito (2010). Effects on egg yolk colour of paprika or paprika combined with marigold flower extracts. Ital. J. Anim. Sci. 9(4): 356-359.

Mladenov, V., A. Marjanović-Jeromela, S. Cvejić, B. Banjac, J. Vollmann, S. Jocić, and D. Miladinović (2017). Preliminary characterization of Camelina sativa L. for the future breeding in Serbia. Selekcija i semenarstvo 23(1): 57-67.

MSZ-08-1908 (1989). Determination of the glucosinolate content of rapeseeds and rapeseed meals. Magyar köztársaság Mezógazdasági és Élelmezésügyi Ágazati Szabvány, MSZH Nyomda és Kiadó Kft: Budapest.

Pekel, A.Y., P.H. Patterson, R.M. Hulet, N. Acar, T.L. Cravener, D.B. Dowler, and J.M. Hunter (2009). Dietary camelina meal versus flaxseed with and without supplemental copper for broiler chickens: Live performance and processing yield. Poult. Sci. 88(11): 2392-2398.

Rabrenović, B.B., V.B. Vujasinović, M.M. Novaković, S.Č. Črbo, and Z.N. Basić (2016). Uporedni prikaz nutritivne vrednosti hladno presovanih ulja semena tikve (Cucurbita pepo L.) različitog porekla. Hem. Ind. 70(1): 59-65.

Rokka, T., K. Alén, J. Valaja, and E.L. Ryhänen (2002). The effect of a Camelina sativa enriched diet on the composition and sensory quality of hen eggs. Food Res. Int. 35(2-3): 253-256.

Rowghani, E., A. Maddahian, and M.A. Abousadi (2006). Effects of addition of marigold flower, safflower petals, red pepper on egg-yolk color and egg production in laying hens. Pakistan J. Biol. Sci. 9(7): 1333-1337.

Santos-Bocanegra, E., X. Ospina-Osorio, and E. OviedoRondón (2004). Evaluation of xanthophylls extracted from Tagetes erectus (Marigold flower) and Capsicum sp. (Red pepper paprika) as a pigment for egg-yolks compare with 
Synthetic pigments. Int. J. Poult. Sci. 3(11): 685689.

Schuster, A. and W. Friedt (1998). Glucosinolate content and composition as parameters of quality of Camelina seed. Ind. Crops Prod. 7(2-3): 297302.

Simopoulos, A.P. (2001). Evolutionary aspects of diet, essential fatty acids and cardiovascular disease. Eur. Heart J. Suppl. 3(D): 8-21.

Simopoulos, A.P. (2009). Evolutionary aspects of the dietary omega-6: omega-3 fatty acid ratio: Medical implications. In 'A Balanced Omega6/Omega-3 Fatty Acid Ratio, Cholesterol and Coronary Heart Disease'. World Review of Nutrition Dietetics, Karger, Basel, Switzerland. 100: 1-21.

Skřivan, M. and M. Englmaierová (2014). The deposition of carotenoids and $\alpha$-tocopherol in hen eggs produced under a combination of sequential feeding and grazing. Anim. Feed Sci. Tech. 190: 79-86.

Skřivan, M., M. Englmaierova, E. Skřivanová, and I. Bubancova (2015). Increase in lutein and zeaxanthin content in the eggs of hens fed marigold flower extract. Czech J. Anim. Sci. 60(3): 89-96.

Spasevski, N., D. Čolović, S. Rakita, P. Ikonić, O. Đuragić, V. Banjac, and Đ. Vukmirović (2016). Fatty Acid Composition and $\beta$-Carotene Content in Egg Yolk of Laying Hens Fed with Linseed,
Paprika and Marigold. Contemporary Agriculture 65(1-2): 15-22.

Spasevski, N., N. Puvača, L. Pezo, T. Tasić, Đ. Vukmirović, V. Banjac, R. Čolović, S. Rakita, B. Kokić, and N. Džinić (2018). Optimisation of egg yolk colour using natural colourants. Europ. Poult. Sci. (Archiv für Geflügelkunde) 82: 1-17.

Tripathi, M.K. and A.S. Mishra (2007). Glucosinolates in animal nutrition: A review. Anim. Feed Sci. Tech. 132(1-2): 1-27.

Tyagi, A.K. (2002). Influence of water soaking of mustard cake on glucosinolate hydrolysis. Anim. Feed Sci. Tech. 99(1-4): 215-219.

Valkonen, E., E. Venäläinen, T. Tupasela, J. Hiidenhovi, and J. Valaja (2007). Camelina sativa cake in layer diets improves yolk fatty acid composition. In Proceedings of the XVIII European symposium on the quality of poultry meat and XII European symposium on the quality of eggs and egg products, Prague, Czech Republic, 8285.

Vasilachi, A., R.D. Criste, M.G. Cornescu, M. Olteanu, T.D. Panaite, S.A. Sredanović, and N. Spasevski (2012). Effect of the dietary camelina meal on layer performance. In Proceedings of the $6^{\text {th }}$ Central European Congress on Food, CEFood2012, Novi Sad, Serbia, 1558-1563.

Whelan, J. and C. Rust (2006). Innovative dietary sources of n-3 fatty acids. Annu. Rev. Nutr. 26: 75-103. 